\title{
Commercial Prospects of under Exploited Leafy Vegetables in India
}

\author{
Basabadatta Sahu* and Samapika Dalai \\ MS Swaminathan School of Agriculture, Centurion University of Technology and \\ Management, Odisha, India-761211 \\ *Corresponding author
}

\section{A B S T R A C T}

\section{Keywords}

Under-exploited crops, uses, distribution

\section{Article Info}

Accepted:

18 May 2020

Available Online:

10 June 2020
Leafy vegetables play a major role in our daily dietary food chart. These nourish us with several nutrients like vitamins and minerals which help in combating against various diseases. Nearly one thousand species of plants with edible leaves are known. Out of which many of them are either grown locally or in rural-tribal areas. On the other hand many are unaware about their existence as well as importance. This paper has been focused on some of them which are widely distributed in various parts of our country India which are categorised as underexploited. They are Sesbania grandiflora, Talinum triangulare, Ipomea aquatic, Chenopodium album, Moringa oleifera, Cucurbita moschata, Marselia quadrifolia, Alternanthera sessilis. These have been found in the Southern and eastern regions of India. These crops need to be expanded quickly for proper nutritional security and prevention against harmful diseases.

\section{Introduction}

India is the country which is blessed with the natural origin of various types of fruits and vegetables which play a major role in our nutrition. And also according to ICMR, a person should consume an average of $300 \mathrm{gm}$ of vegetables and $100 \mathrm{gm}$ of fruits per day. And among vegetables, $50 \mathrm{gm}$ of leafy vegetables, $200 \mathrm{gm}$ of other vegetables and 50 gm of root and tuber crops are needed (Sachdeva et al., 2013). The growth and consumption of leafy vegetables like Amaranthus, Palak Spinach are quite familiar among all as therefore they are categorised into major groups. Their cultivation is widely distributed in our country. But still other leafy vegetable crops are there whose utility and consumption is very rare in our country though they are rich source of several nutrients.

And these crops are categorised into underexploited leafy vegetables. Their commercialisation is needed to give a good impact on the food security. Such crops like Sesbania grandiflora, Talinum triangulare, Ipomea aquatic, Chenopodium album, 
Moringa oleifera, Cucurbita moschata, Marselia quadrifolia, Alternanthera sessilis.

\section{Importance of leafy vegetables}

The photosynthesis process i.e. preparation of food by utilising water and carbondioxide takes place in leaves. Somehow we are consuming the edible parts like fruits in most cases but also leaves and flowers are also being consumed. The plants whose edible part is leaf is considered as leafy vegetable. However, leafy vegetables are rich source of minerals vitamins, moisture (Arasaretnam et al., 2018). If we focus on its cultivation, these are basically short duration crops and requires less maintenance for their growth.

Also they are not heavy feeder of nutrients. Leafy vegetables are regarded as low volume high value crops. Green leafy vegetables have been playing important role in our diet and nutrient and most readily available sources of carbohydrate, fats, proteins, vitamins, minerals, amino acids, fibers. Green leafy vegetables can be processed and stored for future use.

\section{Why underexploited crops?}

Many leafy vegetables exist but very few of them are being commercially grown.

Many are grown and consumed in rural and tribal villages of India.

Furthermore we are unaware about the nutritional, medicinal/therauptic properties of the crops.

As, very lack of research have been conducted son we are unavailing with the desired seeds or planting material for its cultivation.

\section{Potential role of some underexploited leafy vegetables}

\section{Sesbania grandiflora}

It is commonly called as Agathi belongs to Leguminoseae family and it is widely distributed in the areas of Maharashtra, Tamil Nadu, Uttar Pradesh, Assam (Indian Biodiversity Portal). Leaves are alternate compound and pinnate. It is suitable to grow at a temperature of $22-30^{\circ} \mathrm{C}$ and can be grown in wide range of soils. Both leaves and flowers are valued and have nutritional property (Priyanka et al., 2019). Leaves chewed to disinfect mouth and throat. They are excellent source of Vit $\mathrm{C}, \mathrm{Ca}, \mathrm{Fe}$ also (Gowri et al., 2010). 100 gm of agathi leaves contain $93 \mathrm{Kcal}$ energy, $73 \mathrm{gm}$ moisture, $8 \mathrm{~g}$ protein, $1 \mathrm{~g}$ fat, $3 \mathrm{~g}$ mineral, $2 \mathrm{~g}$ fibre, $12 \mathrm{~g}$ carbohydrate, $1130 \mathrm{mg} \mathrm{Ca}, 80 \mathrm{mg}$ phosphorus and $4 \mathrm{mg} \mathrm{Fe}$. Also some amount of iodine and pectin is also present in leaves. Used as aperients, diuretic an also to bruises. Leaf juice has antiurolithiatic activity (Ojha and Diwedi, 1996). Also, regarded as bone strengthener. As it is a leguminous crop, it helps in contributing nitrogen to soil and improves soil fertility.

\section{Talinum triangulare}

It belongs to family Purslane (Portulacaceae). Also known as water leaf or Ceylon spinach. It is widely distributed in regions of Assam, Andhra Pradesh, Karnataka, Tamil Nadu, some parts of Odisha (Indian Biodiversity Portal). It is a succulent plant and known for its growing herbage yield and the chemical composition. It is characterised as tolerant to various soil types, temperature and moisture levels and grow well under shade (Swarna et al., 2015). The leaves of shade loving plant possess great therauptic value in the traditional system of medicinal but have not been fully exploited. (Swarna et al., 2013). 
It is a perennial herb with fleshy green leaves. Popularly k/as water leaf because of its high moisture content of almost $90.8 \mathrm{~g} / 100 \mathrm{gm}$ of edible leaf. It is characterised by the presence of minerals like $\mathrm{Ca}, \mathrm{K}, \mathrm{Mg}$ and vitamins like $\mathrm{C}$ and $B$-carotene. Extract of leaves used to cure Asthma. It consist of several phyochemicals (Anthocyanin, carotenoids, lutein, lycopene, phenolics. The flavonoids like quercetin, haempferol, apigenin which helps against cardiovascular diseases. (Ikewuchi et al., 2017) Water leaf has antiinflaming, anti-fungal and anti-bacterial functions (Adie et al., 2018).

\section{Ipomea aquatic}

It is commonly known as water spinach belongs to family Convolvulaceae. It is found in the areas of Bihar, Madhya Pradesh, Odisha, Rajasthan, Uttar Pradesh, Assam. It is a semi-aquatic tropical plant. It is a quick vigorous plant. This is considered as food with medicinal effects. Used in treatment of various nervous disorders, Gastric and intestinal disorders (Austin, 2007 ). It contains proteins, carbohydrates, crude fibre, vitamins like $\mathrm{A}, \mathrm{B}, \mathrm{C}, \mathrm{E}$ and $\mathrm{U}$ and minerals like $\mathrm{Mg}, \mathrm{Mn}, \mathrm{K}, \mathrm{Fe}$ (Umar et al., 2007). It has been noted that some amount of phenolic compounds, flavonoids, saponins, $\beta$-carotene and ascorbic acid have been found (Dua et al., 2015). Traditionally, it is used in treatment of disorders like diabetes, liver, malfunction, constipation (Chopra et al., 1956).

\section{Chenopodium album}

It is known as bathua belongs to family Amaranthaceae. It is found in the areas of Kashmir, Bihar, Assam, Manipur. It is a fast growing annual plant. Plant is used for local use as a food and medicine. It is reported that bathua contains phenols, tannins, saponin, flavonoids, proteins and trace elements. Also, it has anti-inflammatory, anticancer, antioxidant, antimicrobial, anthelmintic properties (Ali, 2015).Leaves contain minerals like $\mathrm{Na}, \mathrm{K}, \mathrm{Ca}, \mathrm{Mg}, \mathrm{Fe}, \mathrm{Zn}, \mathrm{P}, \mathrm{Cu}$, Mn, N (Adedapo, 2011). Traditionally, used as blood purifier, diuretic, sedative, hepaloprotective, antiscorbutic, laxative, anthelmentic against round and hookworms, ulcer and burns (Amrita et al., 2015 and Agrawal et al., 2014). It provides minerals, fibre, vitamins and essential fatty acids (Amrita et al., 2015). Rich in protein, Vit A, Vit C, Ca, P, Fe, K (Agrawal et al., 2014).

\section{Moringa oleifera}

It is known as drumstick or moringa belongs to family Moringaceae. This is widely known for its fruit in Southern parts of India in preparation of various dishes. Widely distributed in the regions o Maharashtra, Karnataka, Odisha, Bihar, Uttar Pradesh. Varying percentage of nutrients are found in leaves (Bamishanye et al., 2011). Pods and leaves contain high amount of $\mathrm{Ca}, \mathrm{Mg}, \mathrm{K}$, $\mathrm{Mn}, \mathrm{P}, \mathrm{Zn}, \mathrm{Na}, \mathrm{Cu}$ and $\mathrm{Fe}$ (Aslam et al., 2005). Protein has also been found in leaves (Asante etal). Tradiionally leaves are used in treatment of diabetes (Dieye et al., 2014). Leaves contain bioactive components like vitamins, phenolic acids, flavonoids, isothiocyanates, tannins and saponin which help against chronic diseases (Jimenez et al., 2017). Leaves have antioxidant and antiinflammatory properties (Mbikey, 2012 ). Somehow leaves are also processed and preserved for future use (Mishra et al., 2012).

\section{Cucurbita moschata}

It is widely known vegetable for its fruit commonly famous as Pumpkin. In many parts of India and other countries other parts of the plant like leaves are consumed as a cooked vegetable or in the form of soups (Rahman et $a l ., 2019)$. Leaves are widely consumed in the tract of Odisha, Jharkhand region. 
Traditionally, other parts of pumpkin plant except the fruit was also used for medicinal purpose (Yadav et al., 2010 ). Pumpkin leaves contain protein (Ghaly et al., 2010). Besides the consumption of leaves of Cucurbita moschata, leaves of Cucurbita maxima and Cucurbita pepo are also edible.

\section{Marselia quadrifolia}

(Water Clover/ Sunsunia) is a rarely found leafy vegetable in the Odisha, Jharkhand regions of India. It is an aquatic fern belongs to family Marsileaceae that grows from creeping rhizomes. It grows best in the muddy regions of ponds and lakes. It is used as a locally vegetable and also has medicinal properties. It is a good source of protein but low in mineral content like Sodium, potassium (Dewanjii et al., 1993). The leaves used to cure migraine, hypertension, headache (Soni and Singh, 2012). It also contains phytochemical compounds which helps in curing against several diseases like tannins, saponins, flavonoids, phenolic compounds, carbohydrates (Gopalakrishnan et al., 2017).

\section{Alternanthera sessilis}

It belongs to family Amaranthaceae. Commonly known as joyweed or Madranga. This is an annual or perennial prostrate herb. Young shoots and leaves are eaten mostly on eastern parts of India mostly Odisha, Assam, Manipur. Leaves are high in antioxidant property and they protect us from various chronic diseases (Murugan et al., 2013). Leaves are source of moisture, protein, total sugar, some amount of vitamin C (Misra and Misra, 2014). They are locally used for treatment against fever, ophthalmia, gonorrhoea (Behera et al., 2008). It is also a good source for reducing blood sugar level (Hossain et al., 2014 ). It contains phytochemicals like saponin (Walter et al., 2014 and Rao 2018).
Poverty is a major problem in our country for which many are unable to get required amount of nutrient in their daily diet. However, this can be rectified by the various underexploited leafy vegetables such as available locally in rural-tribal areas of India. India is blessed with many such type of leafy vegetable which need to be exploited commercially. These underexploited crops such as Sesbania grandiflora, Talinum triangulare, Ipomea aquatic, Chenopodium album, Moringa oleifera, Cucurbita moschata, Marselia quadrifolia, Alternanthera sessilis are rich source of minerals like $\mathrm{P}, \mathrm{K}, \mathrm{Ca}, \mathrm{Fe}, \mathrm{Mg}, \mathrm{Mn}, \mathrm{Zn}$; vitamins like $\mathrm{A}, \mathrm{B}, \mathrm{C}$; moisture and some amount of proteins. The growth habits of most of these crops are of short duration which hardly requires 3-4 months to obtain the herbage yield. Also these are good source of various phytochemicals such as phenolic acids, flavonoids, tannins, saponins which help in building antioxidant properties in our body to fight against several diseases like chronic diseases, diabetes, etc. Many can be processed and stored for future use. So, focus need to be concerned towards their commercial cultivation and improvement for nutritional security.

\section{References}

Adepado A, Jimoh F and Afolayan A. 2011. Comparison of the nutritive value and biological activities of the acetone, methanol and water extracts of leaves of Bidens pilosa and Chenopodium album. Acta Pol Pharm. 68(1). 83-92.

Adie J.B., Alawa .D.A. and Issac O.2018. Production gap needs of woman farmers in the cultivation of talinum triangulare for enhancing their livelihood in a recessed economy.

Agrawal Y. And El-Shabrawy Mona A. 2014. Phytochemical and Biological Activities of Chenopodium album. 2014. Semantic 
Scholar.

Ali E.S. 2015. The chemical constitutents and Pharmacological effects of Chenopodium album-An overview. International Journal of Pharmacological Screening Methods. 5(1). 10-17.

Amrita P. And Upadhayay A. 2015. Chenopodium album Linn:review of nutritive value and biological properties. Journal of Food science and Technology. 52.3977-3985.

Arasaretnam S., Kiruthika A., Mahendran. 2018. Nutritional and mineral composition of selected green leafy vegetables. Ceylon Journal of Science. 47(1). 35-41.

Aslam M., Anwar F.,Nadeem R.,Rashid U, Kazi T.G., Nadeem M. 2005. Mineral composition of Moringa oleifera leaves and pods from different regions of Punjab, Pakistan.Asian Journal of Plant Science.4. 417-421.

Austin D.F. 2007. Water spinach (Ipomea aquatica, Convolvulaceae) A food gone wild. Ethnobotany Research and Application. 5.123-146.

Bamishaiye E.L., Olayemi F.F., Awagu E.F. Bamishaiye O.M. 2011. Proximate and Phytochemical composition of Moringa leaves at three stages of maturation. Advance Journal of Food Science Technology. 3(4).233-237.

Behera KK, Mishra NM, Rout GR.2008. Potential ethnomedicinal plants at Kaptipada Forest Range Odisha,India and their uses. Journal of Econ Taxon Bot. 32.194-202.

Chopra RN. Nayar SL, Chopra IC. 1956. Glossary of Indian Medicinal Plants. New Delhi, India: Council of Scientific and Industrial Research.

Dery D.T , Asante W.J., Nasare I.L.,Boadu K.O., Kentil K.B. 2014. Nutrient composition of Moringa leaves from two agroecological zones of Ghana.
African Journal of Plant Science.8(1).65-71.

Dewanjii A., Matai S., Si L., Barik S. And Nag A. 1993. Chemical composition of two semi-aquatic plants for food use. Plant foods for Human Nutrition. 44. 11-16.

Dua TK, Dewanjee S, Gangopadhyay M, Khanra R, Zia-Ul-Haq M, De Feo V. 2015. Ameliorative effect of water spinach, Ipomea aquatic (Convolvulaceae) against experimentally induced arsenic toxicity. Jounal of Transl Med. 13-18.

Ghaly A.E. and Alkoaik F.N. 2010. Extraction of Protein from Common Plant leaves for Use as Human food. American Journal of Applied Sciences. 7(3). 331-342

Gopalakrishnan K. and Udaykumar Rajangam. 2017. Phytochemical content of leaf and stem of Marsilea quadrifolia (L.) Journal of Plant Science and Phytopathology. 1. 026-037.

Gowri S.S. Vasantha K. 2010. Free radical scavenging and antioxidant activity of leaves from Agathi(Sesbani grandiflora) . American Journal of Scientific Research. 5(2). 114-119.

Hossain A.I., Faisal M., Rahman S., Jahan R., Rahmutullah M. 2014. A preliminary evaluation of antihyperglycemic and analgesic activity of Alternanthera sessilis aerial parts. BMC Complementary and Alternative Medicine. 14. 169.

Ikewuchi.C.C. Ikewuchi J.C., Ifeanancho M.O. 2017. Bioactive Phytochemicals in an aqueous extract of leaves in Talinum Triangulare. Food Science and Nutrition. 696-701.

Jimenez M.V., Almatrafid M.M. and Fernandez M.L. 2017. Bioactive components in Moringa oleifera leaves protect against chronic diseases. Antioxidants .6.91 
Mbikay M. 2012. Theuraptic potential of Moringa oleifera leaves in chronic hyperglycemic and dislipidemia. Frontiers in Pharmacology. 3.

Mishra S.P., Singh P. And Singh S. 2012. Processing of Moringa oleifera leaves for Human consumption. Bulletin of environment, Pharmacology and Life sciences. 2(1).28-31.

Misra S and Misra M.K. 2014. Nutritional evaluation of some leafy vegetables used by the tribal and rural people of south odisha, India. Journal of Natural Product and Plant Resources. 4(1). 2328.

Murugan SB, Reshma A, Ramamoorthy D, Balamurugan S, Ramalingam S. 2013. Antioxidant capacities of Amaranthus tristis and Alternanthera sessilis : A comparative study. Journal of Medical Plant Resources. 7(30). 2230-2235.

Ojha J.K. and Diwedi K.N. 1996. Effect of plant extracts on non-heading diabetic foot ulcers.Sachitra Ayurved. 48(9). 870-874.

Priyanka T. and Lakshmi K.V .2019. Underutilised and underexploited vegetable crops. JPS Scientific Publication.

Rahman M. M., Juahir H., Islam M.H., Khandaker M.M., Ariff T.M. and Nik W.M. 2019. Prophetic vegetable Pumpkin, Its impressive health benefits and total analysis. Bioscience Research. 16(4). 3987-3999.

Rao. P. 2018. Ayurvedic view of Alternanthera sessilis with special Reference to Mathsyasakshi: A Brief Review. Scifed Journal of Herbal
Medicine. 2(1).

Sachdeva S., Sachdeva T.R., Sachdeva R. 2013. Indian Journal of Community Medicine: Official Publication of Indian Association of Preventive and Social Medicine. 38(4). 192-197.

Soni P. And Singh L. 2012. Marsilea Quadrifolia Linn.A valuable Culinary and Remedial Fern in Jaduguda, Jharkhand, India. International Journal of Lifesciences and Pharma Research. 2(3). 99-104.

Swarna J and Ravindhran R. 2013. Pharmacogonistical and Phytochemical Evaluation of Talinum Traingulare (Jacq.) Wild. International Journal of Pharmacy and Pharmaceutical Sciences. 5(2). 249-256.

Swarna J. And Lokeswari T.S. 2015. Characterisation of Talinum traingulare germplasm using molecular descriptors. South African Journal of Botany. 97. 59-68.

Umar K.J., Hasan L.G., Dangogo S.M. and Ladan M.J. 2007. Nutritional Composition of water spinach (Ipomea aquatic) leaves. Journal of Applied Sciences. 7(6). 803-809.

Walter T.M., Merish S., Tamizhamuthu M. 2014. Review of Alternanthera sessilis with Reference to Traditional Siddha Medicine. International Journal of Pharmacogynosy and Phytochemical Research.6(2). 249-254.

Yadav M., Jain S., Tomar R., Prasad G.B.K.S. and Yadav Hariom. 2010. Medicinal and biological Properties of Pumpkin: updated review. 23. 184-190.

\section{How to cite this article:}

Basabadatta Sahu and Samapika Dalai. 2020. Commercial Prospects of under Exploited Leafy Vegetables in India. Int.J.Curr.Microbiol.App.Sci. 9(06): 2211-2216. doi: https://doi.org/10.20546/ijcmas.2020.906.270 